удк 332.1

Чжан Тяньлэ

Хэйлунцзянская группа «Юань Дун»

Хэйлунцзян. КНР

О проблемах и перспективах развития трансграничного коридора «Харбин - Суйфэньхэ - Россия - Азия» и международного транспортного коридора «Приморье-1»

Zhang Tianle

Heilongjiang Group Yuan Dong

Heilongjiang. China

\title{
On the problems and prospects of development of the cross-border corridor "Harbin - Suifenhe - Russia - Asia" and the international transport corridor "Primorye-1"
}

\author{
Уважаемые участники форума!
}

Приветствую вас от имени Международной транспортной корпорации «Юань Дун» и инвестиционно-логистической компании провинции Хэйлунцзян, основными видами деятельности которых являются международная логистика, торговля, туризм, включая инвестиционные программы в России.

В своем выступлении я затрону тему развития трансграничного коридора наземных и морских грузовых перевозок по маршруту «Харбин - Суйфэньхэ Россия - Азия» и международного транспортного коридора «Приморье-1».

Отправной точкой трансграничного коридора наземных и морских грузовых перевозок по маршруту «Харбин - Суйфэньхэ - Россия - Азия» является город Харбин, который соединен с Владивостоком (г. Находка, порт Восточный) автомобильным и железнодорожным транспортом на восток через г. Суйфэньхэ с дальнейшей отправкой грузов морским путем в города Гуанчжоу, Нинбо, Шанхай (КНР), Пусан (Южная Корея), Ниигата в Японии и другие порты. При стыковке этого трансграничного коридора с российским транспортным коридором «Приморье-1» формируется комплексный коридор для международных перевозок наземного и морского транспорта, соединяющий Северо-Восточную Азию по Шелковому пути.

Схема маршрута международного транспортного коридора «Приморье-1»это Харбин - граница Китая и России - Уссурийск - Владивосток - морской

Чжан Тяньлэ - генеральный директор ООО «Хэйлунцзянская группа «Юань Дун» (КНР). 
путь. Протяженность маршрута 700 километров. Пункты маршрута соединяются китайско-российскими железными и автомобильными дорогами.

C точки зрения грузопотока в направлении на запад импортные и экспортные товары в целом сбалансированы, а соотношение импортных и экспортных грузов составляет $1: 1$. В восточном направлении грузопоток импортных и экспортных товаров серьезно не сбалансирован (объем импортных грузов на переходе Суйфэньхэ составляет 11,81 млн тонн, объем экспортных грузов 431,5 тыс. тонн). Соотношение импортных и экспортных грузов составляет 27:1. Соотношение импортных и экспортных грузов внешнеторгового грузооборота провинции Хэйлунцзян - около 29:1.

В 2017 году внешний товарооборот достиг 2,63 млрд долл. США, т.е. 13,9\% от общей стоимости импорта и экспорта провинции Хэйлунцзян. Среди них объем экспорта составляет 430 млн долл. США, объем импорта - 2,2 млрд долл. США.

В 2017 году объем импорта и экспорта через переход Суйфэньхэ составил 12,23 млн тонн, увеличившись на $30,8 \%$ в сравнении с аналогичным периодом, из которых объем импортных перевозок составил 11,81 млн тонн, увеличившись на $30,6 \%$ в сравнении с аналогичным периодом. Объем экспортных грузов составил 431,5 тыс тонн, увеличившись на $35,1 \%$. Соотношение объемов импортных и экспортных грузов составило 27:1. Большая часть навалочных грузов в основном поступает в такие развитые города Китая, как Далянь, Циндао, Шанхай и Нанкин, лишь 10\% - в Японию и Южную Корею.

Под влиянием многих факторов - структура промышленности, мощность потребления, деловые связи и т.д. - потоки внешней и внутренней торговли в Хэйлунцзяне остаются несбалансированными. Проблема грузового направления и грузового дисбаланса на переходе Суйфэньхэ особенно заметна, что приводит к таким проблемам, как обратный порожняк и холостой прогон на обратном пути. Увеличились расходы на транспортировку товаров и повысилось время транзита товаров, что повлияло на быстрое течение экономических факторов. Проблемы трансграничного коридора наземных и морских грузовых перевозок по маршруту «Харбин - Суйфэньхэ - Россия - Азия» можно условно обобщить как «три дисбаланса» и «шесть узлов».

\section{«Три дисбаланса» на трансграничном коридоре}

1. Пропускная способность разных участков трансграничного коридора не сбалансирована: грузоподъемность несовместима, своевременность перевозки груза не может быть гарантирована.

2. Не сбалансирован общий двусторонний объем товаров, ввозимых и вывозимых через транспортный коридор грузов, разрыв между объемом импорта и объемом экспорта слишком велик.

3. Отмечено неравномерное распределение объема груза в коридоре по оси времени: товары сильно различаются в зависимости от сезона, объемы товаров иногда высоки либо наоборот низки, цена логистики крайне нестабильна. 


\section{Проблемы «шести узлов»}

1. Проблема недостаточной пропускной способности широкой и узкой колеи железной дороги на станции Суйфэньхэ. Проблема «узких мест» для автомобильного и железнодорожного транспорта между Суйфэньхэ и Владивостоком (Восточный порт) достаточно существенная, что выражается в серьезном дисбалансе объема автомобильных грузоперевозок между китайскими и российскими предприятиями, большом различии объемов грузовых перевозок между железными дорогами и автомагистралями, а также маленьких площадях станции Суйфэньхэ, пропускная способность которой для хранения и перевалки грузов недостаточна.

2. Недостаточная пропускная способность таможенного оформления китайско-российских переходов. Время таможенного оформления короткое (8 часов в день), а эффективность таможенного оформления низкая.

3. На некоторых российских железных дорогах отсутствует двухпутная линия, существует проблема недостаточной пропускной способности и высоких тарифов. 26-километровая железная дорога от Суйфэньхэ до Гродеково, смешанные колеи на однопутном участке, отсутствие вспомогательных линий, недостаточная длина двух промежуточных станций на российской стороне. Выходные поезда Суйфэньхэ должны быть сгруппированы, а вторая группа установлена на станции Гродеково, что повлияет на эффективность движения поездов.

От Суйфэньхэ до порта Восточный на российской железной дороге в дополнение к действующему тарифу существуют частные операторы вагонов, которые взимают плату отдельно, проводятся монопольные операции, произвольная корректировка цен, в результате чего общая стоимость логистики коридора слишком высока.

Российская железная дорога не имеет преференциальной политики в отношении грузоперевозок в западном направлении и не может сформировать обратный грузопоток, что не способствует снижению стоимости железнодорожных перевозок. Российские железнодорожные платформы недостаточно обеспечены, при пике транспортировки наблюдается большой разрыв, который влияет на стабильность работы поезда.

Разница в ценах между транспортным средством и платформой велика, что препятствует формированию стабильных рыночных цен. Стоимость железнодорожных перевозок из Суйфэньхэ в порт Восточный в 7 раз превышает стоимость перевозки с Дальнего Востока России на запад.

4. Низкое качество 112 км дорог на российском автомобильном направлении Суйфэньхэ - Находка, стандарт грузовых перевозок не одинаков, что негативно сказывается на бесперебойном движении автомобильного груза. Слишком низкое качество дороги серьезно влияет на эффективность и пропускную способность автомобильного транспорта. Хотя стандарты Международной автомобильной транспортной конвенции поддерживаются в Китае и России, они не единообразны. Из-за ограничения в 43 тонны, действующего в России, Китаю трудно реализовать использование стандартизированных транспортных единиц 
перевозчиков, таких, как контейнеры, полуприцепы и обменные контейнеры в коридоре.

5. Недостаток ресурсов российского портового терминала, высокие портовые и прочие сборы, недостаточная пропускная способность. Существующие портовые и морские фрахтовые расходы порта Владивосток высоки, трудно добиться крупномасштабной и нормальной работы наземного и морского транспорта. Кроме того, размеры российского дальневосточного порта, как правило, невелики: порты Владивосток и Восточный являются двумя крупнейшими профессиональными контейнерными терминалами, тем не менее их годовая пропускная способность составляет всего около 700 тыс. TEU. Эффективность работы порта низкая, а время перехвата обычно составляет более 72 часов. Это намного дольше, чем 24 часа в порту Китая. Все это снижает своевременность доставки грузов.

6. Китайские компании разрабатывают собственные рабочие маршруты, нарушая монополию судоходных компаний. Маршрут из порта Восточного Китая в порт Владивосток и оффшорная монополия на оффшорные мощности лишены автономии и ценовой мощи портов и морских операций. Плотность маршрута низкая, цена высокая, маршрут одиночный. В результате поток товаров на входе и выходе является несбалансированным, трудно добиться «повторного входа и повторного выхода», а объем операций в коридоре сокращается.

Зная проблемы, можно и нужно планировать стратегию и тактику их разрешения. Предлагаются следующие необходимые направления развития трансграничных коридоров.

Необходимо укрепление руководства отраслями, повышение уровня правительственной поддержки, поощрение пилотных предприятий. Используя существующую железнодорожную перегрузочную способность Суйфэньхэ и низко затратную железнодорожную транспортную способность, необходимо повысить пропускную способность грузов маршрута «Китай - Россия - Китай» до 3-4 млн тонн в год путем изменения режима работы и возможностей маршрута. При перевозке крупногабаритных грузов морским и железнодорожным транспортом особенную важность имеет государственная политика таможенной поддержки.

Китайские крупные предприятия могут прийти на Дальний Восток, чтобы найти выгодные портовые условия для создания логистического и транспортного центра, снизить себестоимость портовых услуг, повысить эффективность транспорта порта и удовлетворить потребности крупномасштабных операций. Китай и Россия должны прилагать общие усилия к строительству инфраструктуры транспортного коридора, особенно к повышению пропускной способности транспортного коридора и порта. Китайские предприятия могут построить на Дальнем Востоке собственные порты, обладающие большой пропускной способностью, чтобы удовлетворить потребности в перевозке товаров по транспортному коридору. Китай и Россия должны договориться о том, чтобы в разрешающих участках транзитного транспортного коридора обе стороны назначили особую зону, выдавали лицензию на средства транспорта обеим сторонам и 
упростили оформление таможенной процедуры, чтобы повысить эффективность использования транспорта и развивать транспортный коридор.

При договоренности руководителей двух государств высшего уровня обе стороны разработали содержательное рамочное соглашение, осуществили всестороннее сопряжение трансграничного коридора наземных и морских грузовых перевозок по маршруту «Харбин - Суйфэньхэ - Россия - Азия» и международного транспортного коридора «Приморье-1». В будущем мы намерены развивать межрегиональную связь, особенно на провинциальном и областном уровнях, укрепить обмен между народами и предприятиями, чтобы в течение трех лет пропускная способность коридора повысилась до 35 млн тонн в год.

Завершая свое выступление, хочу отметить, что, так как я учился в России и многие годы работаю в сотрудничестве с российскими компаниями, это дает мне право считать Россию своей второй Родиной. Я особенно заинтересован и надеюсь на дальнейшее развитие международных взаимовыгодных российскокитайских отношений.

() Чжан Тяньлэ, 2019

Для цитирования: Чжан Тяньлэ. О проблемах и перспективах развития трансграничного коридора «Харбин - Суйфэньхэ - Россия - Азия» и международного транспортного коридора «Приморье-1» // Территория новых возможностей. Вестник Владивостокского государственного университета экономики и сервиса. 2019. Т. 11, № 2. С. 8-12.

For citation: Zhang Tianle. On the problems and prospects of development of the cross-border corridor "Harbin - Suifenhe - Russia - Asia" and the international transport corridor "Primorye-1", The Territory of New Opportunities. The Herald of Vladivostok State University of Economics and Service, 2019, Vol. 11, № 2, pp. 8-12. 